\title{
Injected with Controversy: Sales and Administration Of Injectable Contraceptives in Drug Shops in Uganda
}

By John Stanback,
Conrad Otterness,
Martha Bekiita,
Olivia Nakayiza
and Anthony K.
Mbonye

John Stanback is deputy director and Conrad Otterness is research associate, both with Family Health International, Durham, NC, USA. At the time the research was completed, Martha Bekiita was reproductive health technical advisor, and Olivia Nakayiza was program officer, both with Save the Children, Uganda. Anthony K. Mbonye is Commissioner of Family Planning, Ministry of Health, Kampala, Uganda.

CONTEXT: Informal drug shops are the first line of health care in many poor countries. In Uganda, these facilities commonly sell and administer the injectable contraceptive depot medroxyprogesterone acetate (DMPA), even though they are prohibited by law from selling any injectable drugs. It is important to understand drug shop operators'current practices and their potential to provide DMPA to hard-to-reach populations.

METHODS: Between November 2007 and January 2008, 157 drug shops were identified in three rural districts of Uganda, and the operators of the 124 facilities that sold DMPA were surveyed. Data were analyzed with descriptive methods.

RESULTS: Only 35\% of operators reported that the facility in which they worked was a licensed drug shop and another 9\% reported that the facility was a private clinic; all claimed to have some nursing, midwifery, or other health or medical qualification. Ninety-six percent administered DMPA in the shop. Operators gave a mean of 10 injections (including three of DMPA) per week. Forty-three percent of those who administered DMPA reported disposing of used syringes in sharps containers; in the previous 12 months, $24 \%$ had had a needle-stick injury and $17 \%$ had had a patient with an injection-related abscess. Eleven percent said they had ever reused a disposable syringe. Overall, contraceptive knowledge was low, and attitudes toward family planning reflected common traditional biases.

CONCLUSION: Provision of DMPA is common in rural drug shops, but needs to be made safer. Absent stronger regulation and accreditation, drug shop operators can be trained as community-based providers to help meet the extensive unmet demand for family planning in rural areas.

International Perspectives on Sexual and Reproductive Health, 2011,37(1):24-29, doi: 10.1363/3702411

\section{INTRODUCTION}

Informal drug shops are often the first line of health care for the poor in many developing countries. Not to be confused with pharmacies, drug shops do not ordinarily employ pharmacists and are legally allowed to sell only nonprescription, prepackaged medicines. A varied literature harshly critiques the quality of services that drug shops provide, ${ }^{1-3}$ but also praises their accessibility and low cost, ${ }^{3-5}$ noting in particular the gap they fill in underserved rural areas. One study, in which interactions between drug shop operators and their customers were observed, concluded that clients viewed drug shop operators not only as commercial outlets for medicines, but also as health care providers who dispensed advice and guidance. ${ }^{6}$

In Uganda, drug shops are distinct from pharmacies in several ways. Legally, drug shops can sell only nonprescription drugs, and must be registered with the Uganda National Drug Authority (NDA) and be owned by medically qualified persons with at least nursing or midwife training; nonowner operators must have received training at least at the level of nursing aide. Prior to registration, drug shops must first be inspected for suitability of the premises, and after being registered, they are supposed to be regularly monitored by district drug inspectors who act on behalf of the NDA. ${ }^{7}$ In 2008 , there were 4,742 regis- tered drug shops in Uganda, more than 10 times the number of pharmacies. ${ }^{8}$

In practice, drug shops in Uganda often sell a variety of prescription drugs-including those requiring injectionand also provide care and treatment, ${ }^{9}$ even though $30 \%$ of drug shop attendants lack any medical qualifications, according to one study. ${ }^{10}$ Drug shops are found not only in cities and towns, but also in small trading centers and rural areas. Many are not registered with the NDA as drug shops, but rather operate in the shadows of legitimacy, using the same trading license as simple shopkeepers, or sometimes no license at all. Even unlicensed drug shops, however, operate openly, implying lax inspection and enforcement standards. Typical drug shops in rural Uganda are storefronts with product displays and a counter; however, nearly all have a curtained back room where clients can be seen-and often treated-in private.

Most drug shops legally sell over-the-counter family planning methods such as oral contraceptives and condoms, usually social marketing brands. Many also sell and administer the three-month injectable contraceptive Depo Provera (depot medroxyprogesterone acetate, or DMPA), even though both the sale and the administration of any injectable drug by drug shops are illegal. ${ }^{7}$ In light of 
Uganda's low modern contraceptive prevalence rate (18\%) and its ongoing health worker shortage, a strong case can be made for building the capacity of drug shop operators to safely provide the injectable contraceptivethe most popular method in the country. ${ }^{11}$ Uganda's Ministry of Health has already sanctioned provision of the injectable by community health workers, a group generally far less qualified than typical drug shop operators. To better understand current practices by drug shop operators and their potential to provide the injectable to hard-toreach populations, we visited shops in three districts and surveyed their operators.

\section{METHODS}

\section{Study Design and Sample}

Between November 2007 and January 2008, we used local informants and "snowball sampling" techniques to attempt to contact all drug shops and small private clinics* in three rural districts north of Kampala (Nakasongola, Luwero and Nakaseke) where one of the study partners, Save the Children-USA, was active. Drug shop operators who reported selling DMPA were eligible to participate in the study. Of the 157 operators identified in the three districts, 124 (79\%) met the inclusion criterion, and all 124 agreed to participate. The study design was approved by the Protection of Human Subjects Committee of Family Health International (FHI).

\section{Data Collection and Analysis}

Health extension workers and community reproductive health workers affiliated with Save the Children-USA in Uganda interviewed the drug shop operators using an eight-page survey instrument that assessed details of sales and injection practices, knowledge of screening and counseling for hormonal methods, technical knowledge of safe injection skills and attitudes toward family planning. Typically, interviews were conducted in the shops between client visits, in the local language-Luganda-and took less than 30 minutes. Data were entered by clerks at Save the Children-USA in Luwero. Data cleaning took place in Uganda and at Family Health International (FHI) headquarters in North Carolina, USA, and data were analyzed by FHI staff in North Carolina. Because of the observational nature of the research and the absence of hypothesis testing, all analyses were descriptive. We summarized data using frequencies and percentages, or means and ranges where appropriate.

\section{RESULTS}

Seven in 10 respondents were female. Sixty-nine percent operated facilities in rural areas, and $27 \%$ did so in small towns, villages or trading centers (Table 1). Three-quarters

*In the rural areas surveyed, there was little difference between entities that called themselves drug shops and those that called themselves private clinics. Their operators had similar backgrounds, nearly all the drug shops provided health care services and nearly all the private clinics sold a wide variety of drugs and medical supplies.
TABLE 1. Percentage distribution of drug shop operators who sold the injectable contraceptive, by selected characteristics, Uganda, 2007-2008

Characteristic $\%$

\section{Gender}

Male

Female

Location of facility

Town

Rural

No response

27

Facility type

Drug shop

Private clinic

Combined drug shop-private clinic

Other

Official status of facility

No license

Licensed drug shop

Licensed private clinic

Trading license

\section{Owns facility}

Yes

No

Provider qualification

Nurse

Midwife

Nursing aide

Auxiliary nurse

Other nurse/health/medical

77

15

7

2

6

35

9
50

Ever had formal family planning training

Yes

No

Ever had safe injection training

Yes

No

38

Ever had infection prevention and control training

Yes

No

59

Total

100

Note:Percentages may not add to $100 \%$ because of rounding or missing values.

(77\%) identified their facilities as drug shops, whereas the rest identified them as private clinics, combined drug shop-private clinics or other types of facilities; none were pharmacies. Fewer than half of the facilities were actually licensed as drug shops (35\%) or private clinics (9\%); the majority reported having either a simple trading license (50\%) or no license (6\%). Only about half (48\%) of the respondents reported owning the facility in which they worked.

In regard to their provider qualifications, $33 \%$ of operators reported being nursing aides, 26\% nurses, $7 \%$ midwives and 4\% auxiliary nurses; the remaining 30\% reported a variety of other nursing and medical backgrounds. Most respondents said they had had formal training in family planning (77\%), injection safety (62\%), or infection prevention and control (59\%). Respondents reported a mean of five years of experience in providing family planning (not shown). 
TABLE 2. Selected contraceptive provision characteristics of drug shop operators who sold the injectable contraceptive

\begin{tabular}{lc} 
Characteristic & \% or mean \\
\hline PERCENTAGE DISTRIBUTIONS & \\
Type of DMPA sold & \\
Injectaplan (social marketing) & 17 \\
Loose vials & \\
Injected DMPA in shop & 96 \\
Yes & 4 \\
No & \\
Syringe type sold/used & 89 \\
Autodisable syringe (Soloshot) & 10 \\
Normal disposable syringe & 1 \\
No response & 100 \\
Total & \\
MEAN & 3.5 \\
No. of DMPA doses sold per week & $0-20$ \\
Range & \\
\hline
\end{tabular}

Note:DMPA=depot medroxyprogesterone acetate.

\section{Services Provided}

Operators reported selling a mean of 3.5 doses of DMPA per week (Table 2); 83\% reported selling the social marketing Injectaplan brand, and 17\% sold loose vials. The vast majority (96\%) of operators administered the injectable themselves in the shop; $89 \%$ sold or used the autodisable SoloShot syringe included in the Injectaplan package.* Those who did not administer injections usually referred clients to qualified providers in the public or private sector for injections (not shown). Prices for DMPA were modest, usually the labeled social-marketing price plus a small amount (about US\$ 0.65).

\section{Safe DMPA Provision}

Ninety-four percent of operators reported taking clients' medical history before providing DMPA (Table 3). Of those, $78 \%$ asked about pregnancy or menstruation status; $47 \%$ about heart condition, stroke or clots; and $41 \%$ about unusual bleeding. Forty percent of operators reported keeping a register of their DMPA clients-86\% of whom said they included the due date for the next injection (not shown).

Drug shop operators reported giving a mean of 10 injections a week, about three of which were DMPA (Table 3). Of those who administered the injectable, fewer than half (43\%) disposed of syringes in a sharps container immediately after use. This was corroborated by interviewer reports of visible, loose used syringes in $41 \%$ of the facilities and sharps in open containers in $58 \%$ of facilities (not shown). Only 27\% reported having access to free sharps containers, such as those widely supplied to clinics by UNICEF and USAID. Regardless of what container was used for initial disposal, nearly all operators reported ultimately disposing of their used syringes either in pit latrines (51\%) or by burn-

*Autodisable syringes are those designed with a mechanism that prevents them from being used more than once. ing (54\%). (Deep pit latrines may be suitable for disposal of low-volume medical waste, but these drug shops demonstrated a need for better waste disposal, such as by high temperature incineration.) Twenty-four percent of operators who administered DMPA had had at least one needle-stick injury in the past year, and $17 \%$ had had at least one patient suffer an injection-related abscess in the past year-typically caused by unsterile needles or poor injection technique, although not necessarily from a DMPA injection. Finally, 11\% reported ever reusing a disposable syringe because of lack of supplies.

\section{Safe Injection Knowledge}

Of operators who injected DMPA, nearly all (95\%) knew that disposable syringes cannot be sterilized and reused safely (Table 4). When asked the steps they follow in providing DMPA, only 45\% spontaneously reported washing their hands, and $42 \%$ reported checking the expiration date on the injection bottle. Forty percent mentioned following the correct practice of gently shaking the bottle or

TABLE 3. Selected provision and safety characteristics of
drug shop operators who sold the injectable contraceptive

Characteristic

$\%$ or mean

PERCENTAGES

Took medical history of new clients

before providing DMPA

94

Medical conditions/history asked about*,+

Pregnancy/menstruation

Heart condition/stroke/clot

Breast cancer

Unusual bleeding

Blood pressure/hypertension

Liver disease

Disposal of used syringes immediately after injection‡

Sharps container

Open bowl/container

Pit latrine

Other/no response

48

7

Had access to free sharps containers $¥$

27

Disposal of used syringes at the end of

the day/when container was fullt, $\neq$

Bury

Pit latrine

Burn

Garbage pit

Taken by immunizers

Had $\geq 1$ needle-stick injury in previous 12 mos.

24

$\mathrm{Had} \geq 1$ patient with injection-related

abscess in previous 12 mos.‡

17

Ever reused disposable syringe because

of lack of supplies

11

MEANS

No. of injections per week

Range

No. of DMPA injections per week

Range

3.2

$0-20$

*Of the 117 who took clients' medical history before providing DMPA. †Respondents could give more than one answer. $\neq$ Of the 119 who inject DMPA.Note: DMPA=depot medroxyprogesterone acetate. 


\begin{tabular}{|c|c|}
\hline Measure & $\begin{array}{l}\% \\
(\mathrm{~N}=119)\end{array}$ \\
\hline \multicolumn{2}{|c|}{$\begin{array}{l}\text { No. of times regular disposable syringes can safely } \\
\text { be sterilized and reused }\end{array}$} \\
\hline None/never & 95 \\
\hline Any other answer & 5 \\
\hline \multicolumn{2}{|l|}{ Injection practices mentioned* } \\
\hline Wash hands & 45 \\
\hline Check expiration date on injection bottle & 42 \\
\hline Shake bottle gently/turn upside down 2-3 times & 40 \\
\hline Shake bottle well & 54 \\
\hline \multicolumn{2}{|c|}{ What to do if one inserts needle into a client and draws blood } \\
\hline Remove needle and try another spot & 79 \\
\hline Any other answer & 15 \\
\hline Don't know & 6 \\
\hline \multicolumn{2}{|l|}{$\begin{array}{l}\text { Diseases mentioned as transmitted through } \\
\text { unsafe injection/needle-stick injuries* }\end{array}$} \\
\hline HIV & 82 \\
\hline Hepatitis B & 6 \\
\hline Hepatitis C & 4 \\
\hline
\end{tabular}

turning it upside down several times before use, whereas $54 \%$ reported the incorrect practice of shaking the vial vigorously. Seventy-nine percent of the operators knew to remove the needle and try a different spot if blood is aspirated during injection. Finally, four-fifths of respondents knew at least one disease transmissible through unsafe injections or needle-sticks, though knowledge was mostly limited to HIV, with fewer than $10 \%$ mentioning hepatitis B or C.

\section{Contraceptive Knowledge}

When asked which contraceptive methods they knew about (besides the injectable), nearly all respondents mentioned oral contraceptives (97\%), and smaller proportions spontaneously mentioned condoms (90\%), the IUD (61\%), the implant (63\%), male and female sterilization

\begin{tabular}{|lc|}
\hline $\begin{array}{l}\text { TABLE 5. Percentage of drug shop operators, by specific } \\
\text { measures of DMPA-specific knowledge }\end{array}$ \\
Knowledge & $\%$ \\
& $(\mathrm{~N}=124)$ \\
\hline DMPA contraindications mentioned* & \\
Unexplained vaginal bleeding & 36 \\
Severe high blood pressure & 30 \\
History of heart disease & 9 \\
Severe liver disease & 7 \\
History of breast cancer & 2 \\
Serious side effects requiring medical attention** & \\
Very heavy bleeding & 87 \\
Severe headache & 52 \\
Chest pain & 19 \\
Pregnancy & 16 \\
& \\
Duration of pregnancy protection & 100 \\
3 months/12 weeks & 0 \\
Other & \\
\hline *Respondents could give more than one answer.Note: DMPA=depot medroxy- \\
progesterone acetate.
\end{tabular}

(38\% and $44 \%$, respectively), fertility awareness methods (15\%) and lactational amenorrhea/breast-feeding (12\%).

To assess specific knowledge about DMPA, respondents were asked open-ended, multiple-response questions about the method's contraindications, advantages and disadvantages, and side effects. Only 16\% of respondents could name more than one contraindication; $47 \%$ recalled one, and $37 \%$ could not correctly name any. Unexplained vaginal bleeding and severe high blood pressure were the most commonly mentioned contraindications (36\% and $30 \%$, respectively; Table 5). Few respondents could name any noncontraceptive benefits of DMPA, but nearly all knew one or more common side effects (not shown): For example, $75 \%$ reported headache as a side effect, $69 \%$ heavy bleeding, $59 \%$ irregular bleeding, $44 \%$ weight gain and $44 \%$ spotting. Only 39\% spontaneously reported amenorrhea as a side effect, although it is eventually experienced by nearly all users. Most respondents knew only one or two of the four serious but rare side effects that require medical attention, such as "very heavy bleeding" $(87 \%)$.

All respondents knew that DMPA provides reliable contraceptive protection for three months (Table 5). When asked how late a client could be for her injection without the contraceptive losing its effectiveness, only $21 \%$ of respondents said two weeks, the "grace period" recommendation at the time in Uganda, ${ }^{*}$ whereas $46 \%$ thought the grace period was less than two weeks (not shown)

\section{Family Planning Attitudes}

Operators were asked a series of questions about family planning knowledge and attitudes. Broadly speaking, operators held traditional views, such as that "a woman needs her husband's permission before using a contraceptive like Depo Provera" (75\% agreed) and that "contraception encourages promiscuity among adolescents" ( $51 \%$ agreed). Some of the agree-disagree questions also provided a measure of respondents' technical knowledge of family planning. Most respondents (75\%) correctly disagreed with false statements about DMPA causing permanent sterility. On the other hand, only 44\% correctly disagreed with the statement "Depo Provera can only be given to a woman on a day when she is menstruating."

\section{DISCUSSION}

This survey revealed characteristics of a group of women and men who actively sell and inject DMPA in drug shops in rural Uganda. Although illegal, this practice almost certainly provides a much needed service, given the context of high maternal mortality and morbidity, poorly stocked clinics and high unmet need for family planning.

Many drug shop operators are fully qualified nurses and

*Currently, the World Health Organization recommends that DMPA users be assessed for pregnancy only when they are at least one month late for reinjection (Source:World Health Organization, Selected Practice Recommendations for Contraceptive Use, 2008 Update, 2008, <http://whqlibdoc.who.int/hq/2008/WHO_RHR_08.17_eng.pdf >, accessed Feb. 22, 2011). 
midwives who, we believe, should be encouraged to continue providing family planning services to poor, rural women. Other operators are less qualified, but in the current regulatory environment, will likely continue to sell and administer the injectable. All providers-no matter their qualifications-would benefit from training or retraining in safe injection skills and family planning counseling, as well as from better access to safe waste disposal and, ideally, medical supervision. This is not a radical idea: In Uganda and elsewhere, community health workers with limited training safely and legally provide the injectable. ${ }^{12-15}$ Given the higher training and experience of drug shop operators-nearly all of those in our sample reported some clinical background-training them as community-based distribution agents makes good sense and could be done without the highly complicated process of changing Uganda's regulatory and policy environment. If properly undertaken, and with the institution of some element of ongoing supervision, such training could also have the important benefit of decreasing the number of unsafe and unnecessary injections of other drugs. (DMPA shots are probably the safest injection provided in Uganda's thousands of drug shops, because the social marketing version bundles a autodisable syringe with every vial.)

In the long run, of course, accreditation of trained providers and stronger enforcement of licensing and safety regulations are desirable and could make drug shops a stronger partner in Uganda's efforts to improve public health and achieve its Millennium Development Goals. For their part, drug shop owners need to take more seriously the responsibility of licensing their shops and employing qualified operators. In the meantime, however, our survey points to the immediate need for training and supervision, as well as universal access to puncture-proof sharps containers and the marketing and informational materials available to legal purveyors of social marketing injectables. In fact, this process may have started: Subsequent to our research, Uganda's principal family planning social marketing group trained 150 drug shop operators in four districts to safely provide injectable contraceptives. The training intervention, however, remains limited, and official policies have not changed.

\section{REFERENCES}

1. Goodman C et al., Drug shop regulation and malaria treatment in Tanzania-why do shops break the rules, and does it matter? Health Policy and Planning, 2007, 22(6):393-403.

2. Tumwikirize WA et al., Management of acute respiratory infections in drug shops and private pharmacies in Uganda: a study of counter attendants' knowledge and reported behaviour, East African Medical Journal, 2004, 81(Suppl.):S33-S40

3. Brugha R and Zwi A, Improving the quality of private sector delivery of public health services: challenges and strategies, Health Policy and Planning, 1998, 13(2):107-120.

4. Mills A et al., What can be done about the private health sector in low-income countries? Bulletin of the World Health Organization, 2002, 80(4):325-330.

5. Ajayi OO, Contraceptive Knowledge and Compliance with Guidelines for Providing Contraceptive Services by Patent Medicine
Vendors in Ibadan North Local Government Area, unpublished dis sertation, Ibadan, Nigeria: University of Ibadan, 2009.

6. Brieger WR et al., Interactions between patent medicine vendors and customers in urban and rural Nigeria, Health Policy and Planning, 2004, 19(3): 177-182.

7. Uganda National Drug Authority, Licensing Requirements and Guidelines for 2011, Kampala, Uganda: Uganda National Drug Authority, 2010.

8. Uganda Ministry of Health, Pharmaceutical Situation Assessment, Level II Health Facilities Survey, Report of a survey conducted July-August 2008, Dec. 2008, <http://apps.who.int/medicinedocs/documents/ s16377e/s16377e.pdf>, accessed Feb. 1, 2011.

9. Adome RO, Whyte SR and Hardon A, Popular Pills: Community Drug Use in Uganda, Amsterdam: Het Spinhuis, 1996.

10. Uganda Ministry of Health, National Communication Strategy for Promoting Rational Use of Medicines, May 2009, <http://apps.who.int/ medicinedocs/documents/s1651le/s1651le.pdf>, accessed Feb. 1, 2011.

11. Uganda Bureau of Statistics (UBOS) and Macro International, Uganda Demographic and Health Survey, 2006, Calverton, MD, USA UBOS and Macro International, 2007.

12. Stanback J et al., Community-based health workers can safely and effectively administer injectable contraceptives: conclusions from a technical consultation, Contraception, 2010, 81(3):181-184.

13. Malarcher S et al., Provision of DMPA by community-health workers: what the evidence shows, Contraception, 2011 (forthcoming).

14. Stanback J, Mbonye A and Bekiita M, Contraceptive injections by community health workers in Uganda: a nonrandomized community trial, Bulletin of the World Health Organization, 2007, 85(10):768-773.

15. Government of Uganda, Addendum to Section 3.8.2 of the 2006 National Policy Guidelines and Service Standards for Sexual and Reproduction Health, 2011.

\section{RESUMEN}

Contexto: En muchos países pobres, las droguerías informales constituyen la primera línea de atención a la salud. En Uganda, estos lugares comúnmente venden y aplican el anticonceptivo inyectable acetato de medroxiprogesterona de depósito (DMPA según sus siglas en inglés), aun cuando están prohibido por ley vender medicamentos inyectables. Es importante comprender las prácticas actuales de quienes operan estos comercios de medicamentos y su potencial para proporcionar DMPA a poblaciones de difícil acceso.

Métodos: Entre noviembre de 2007 y enero de 2008, se identificaron 157 droguerías en tres distritos rurales de Uganda, y se aplicó una encuesta a los encargados de 124 de esos comercios que vendían DMPA. Los datos fueron analizados con métodos descriptivos.

Resultados: Solamente 35\% de los encargados informaron que el comercio en el que trabajaban tenía una licencia de farmacia; y otro 9\% informó que se trataba de una clínica privada; todos afirmaron tener alguna acreditación en enfermería, partería u otra especialidad médica o de salud. Noventa y seis por ciento aplicaba DMPA en el punto de venta. Los encargados distribuian un promedio de 10 inyecciones (incluidas tres de DMPA) por semana. Cuarenta y tres por ciento de quienes aplicaban DMPA informaron que desechaban las jeringas usadas en contenedores de objetos filosos. En los 12 meses anteriores, $24 \%$ habia tenido una herida producida por aguja y $17 \%$ habia tenido un paciente con un absceso relacionado con la inyección. Once por ciento dijo haber reutilizado alguna vez 
una jeringa desechable. En general, el conocimiento sobre anticoncepción era bajo y las actitudes hacia la planificación familiar reflejaban prejuicios tradicionales comunes.

Conclusión: La provisión de DMPA es común en comercios rurales, pero necesita hacerse más segura. En ausencia de una regulación más enérgica y de acreditación, los encargados de las droguerías informales pueden ser capacitados como prestadores comunitarios (quienes pueden aplicar inyecciones de manera legal) para ayudar a satisfacer la extensa demanda insatisfecha de planificación familiar en las áreas rurales.

\section{RÉSUMÉ}

Contexte: Les pharmacies informelles sont la première ligne de soins de santé dans de nombreux pays pauvres. En Ougan$\mathrm{da}$, ces établissements vendent et administrent fréquemment le contraceptif injectable DMPA (acétate de médroxyprogestérone-dépôt), même si la loi leur interdit la vente de médicaments injectables. Il importe de comprendre les pratiques courantes des exploitants de ces pharmacies et leur potentiel d'apport du DMPA aux populations difficiles d'accès.

Méthodes: Entre novembre 2007 et janvier 2008, 157 pharmacies informelles ont été identifiées dans trois districts ruraux ougandais. Une enquête a été menée auprès des exploitants des 124 établissements qui vendaient le DMPA. Les données obtenues ont été analysées par méthodes descriptives.

Résultats: Seuls 35\% des exploitants ont déclaré que l'établissement dans lequel ils travaillaient était une pharmacie agréée. Neuf pour cent ont pour leur part déclaré qu'il s'agissait d'une clinique privée. Tous ont déclaré avoir une certaine qualification en soins infirmiers, obstétriques (sages-femmes) ou autres compétences de santé ou médicales. Quatre-vingtseize pour cent administraient le DMPA. Les exploitants pratiquaient en moyenne 10 injections (dont trois de DMPA) par semaine. Quarante-trois pour cent de ceux qui administraient le DMPA ont déclaré jeter les seringues usagées dans un réceptacle approprié; durant les 12 mois précédant l'enquête, 24\% s'étaient blessés par piqûre d'aiguille et $17 \%$ avaient eu au moins un cas d'abcès au site d'injection. Onze pour cent ont dit avoir réutilisé une seringue jetable. Dans l'ensemble, la connaissance de la contraception était faible et les attitudes à l'égard de la planification familiale reflétaient les préjugés traditionnels courants.

Conclusion: La fourniture de DMPA est courante dans les pharmacies informelles des milieux ruraux. Elle doit cependant être rendue plus sûre. À défaut d'une réglementation ou de conditions d'homologation plus strictes, les exploitants de ces pharmacies peuvent être formés au titre de prestataires communautaires (légalement autorisés à pratiquer des injections) pour aider à répondre à l'importante demande de planification familiale non satisfaite dans les milieux ruraux.

\section{Acknowledgments}

Funding for the research contained in the article was provided by the United States Agency for International Development (USAID). The authors thank the staff of the Uganda offices of Family Health International and Save the Children for their invaluable assistance.

Author contact:jstanback@fhi.org 